Bull. Geol. Soc. Finland 41, 57-63 (1969)

\title{
PALEOMAGNETISM OF THE DIKE SYSTEMS IN FINLAND IV REMANENT MAGNETIZATION OF THE DOLERITE AND RELATED DIKES IN THE ÅLAND ARCHIPELAGO
}

\author{
K. J. Neuvonen and Leo Grundström \\ Institute of geology, University of Turku, Finland
}

\begin{abstract}
The dikes of the area can be divided into three groups having different directions of remanent magnetization after demagnetization in the AC field. One of these groups has a direction which coincides with that measured for the Jotnian dolerites in the Satakunta and Vaasa archipelago. The direction of the second group differs but slightly from this and the third one has a reversed orientation. The age relations and the origin of the magnetization are discussed.
\end{abstract}

\section{CONTENTS}

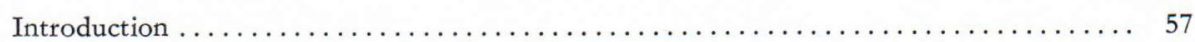

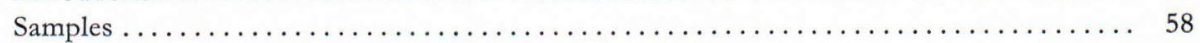

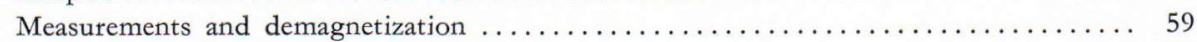

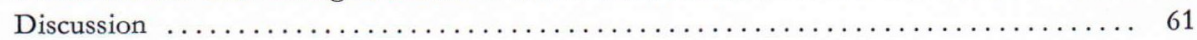

\section{Introduction}

Basic dike rocks are abundant and well exposed in the region of the Alland (Ahvenanmaa) archipelago. According to Sederholm (1890, 1934) the following sequence of dikes can be observed:

1) well preserved olivine diabase (dolerite) on the islands of Märket and Sankan in the Aland Sea and near the shore of Eckerö. The rock is the youngest of the intrusive dikes in the region and certainly younger than rapakivi granite because it is found as dikes penetrating it (Fig. 1).

2) coarse grained, plagioclase rich (ossipite) diabase in the region outside the rapakivi granite area. According to Frosterus (1892), these dikes are younger than rapakivi, but Sederholm (1934) and Hausen (1964) consider them to be somewhat older than rapakivi granite and associated granophyric dikes. The greatest number of these dikes is encontered in an area SE of Föglö and in the SW part of Eckerö (Fig. 1). 


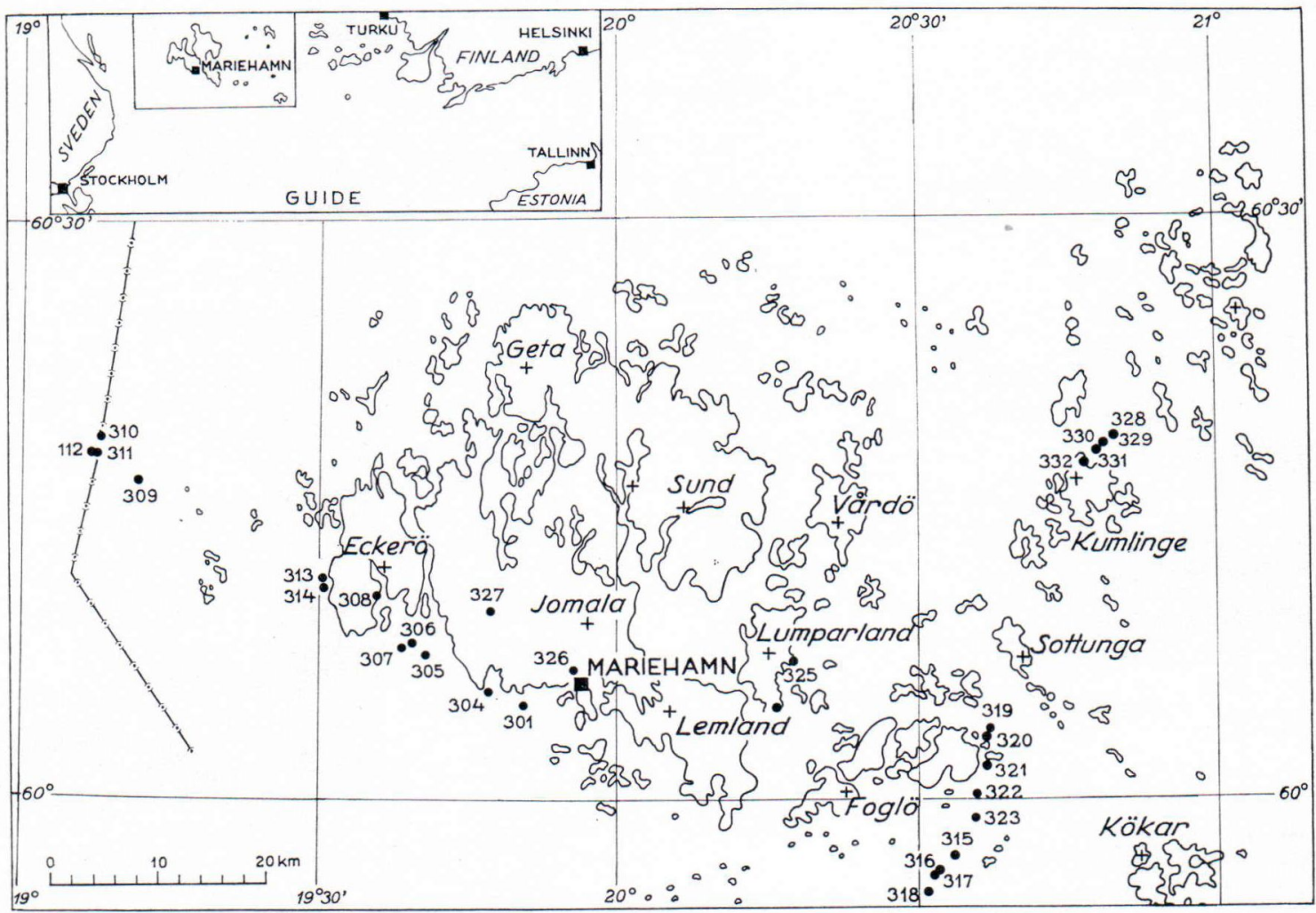

Fig. 1. Sample sites and the locality of the Aland archipelago.

3) unfolded diabase dikes cutting through the gneisses and older granites of the area but which are clearly older than rapakivi granite. These dikes are especially abundant in the Kumlinge region (Fig. 1).

4) the oldest metabasaltic and lamprophyric dikes in the gneissous complex of the region only. Many of the dikes are folded and broken into pieces by tectonic movements.

Additional dike rocks occur in the northern part of Aland in connection with the Ava ringintrusion (Kaitaro, 1952). These dikes are not, however, included in the present presentation but will receive special consideration at a later date (Neuvonen, 1969).

\section{Samples}

Oriented samples were drilled of the dikes mentioned. The oldest dike system could not, however, be measured because of weak and unstable magnetization. The samples collected are concentrated into three groups:

a) Märket diabase representing dikes younger than rapakivi granite, station numbers 308-314.

b) Föglö diabase, age uncertain but probably somewhat older than rapakivi granite, numbers $315-322$.

c) Kumlinge diabase representing dikes clearly older than rapakivi granite, numbers 328-331. 
TABLE 1

Modal mineral composition of some diabase dikes in the Aland (Ahvenanmaa) archipelago

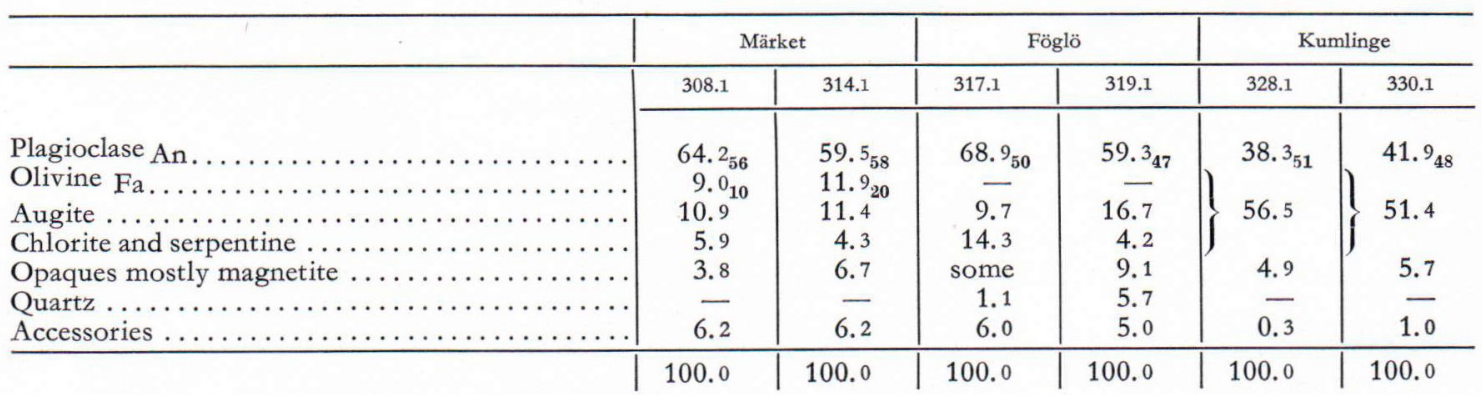

Table 1 gives the mineral composition of some of the samples of each type of rock collected for investigation. Märket diabase (dolerite) is the best preserved of them all. It is usually coarse grained and frequently contains forsteriterich olivine. Föglö diabase contains no olivine, is also very coarse-grained and rich in plagioclase. Similar diabases and associated composite dikes SW of Eckerö are too weakly magnetized to be measured and are omitted. The Kumlinge diabase usually contains some olivine but the rock is so fine grained that the different dark minerals are not distinguished in the mode analyses listed.
Magnetite is the dominant opaque mineral in all the rocks measured but ilmenite lamellae are met with in all types. Individual ilmenite grains are abundant in the Föglö diabase.

\section{Measurements and demagnetization}

The strength and direction of NRM was measured with the astatic magnetometer using the same technique as before. The results are listed in the first part of Table 2. Most of the samples measured showed a similar variation
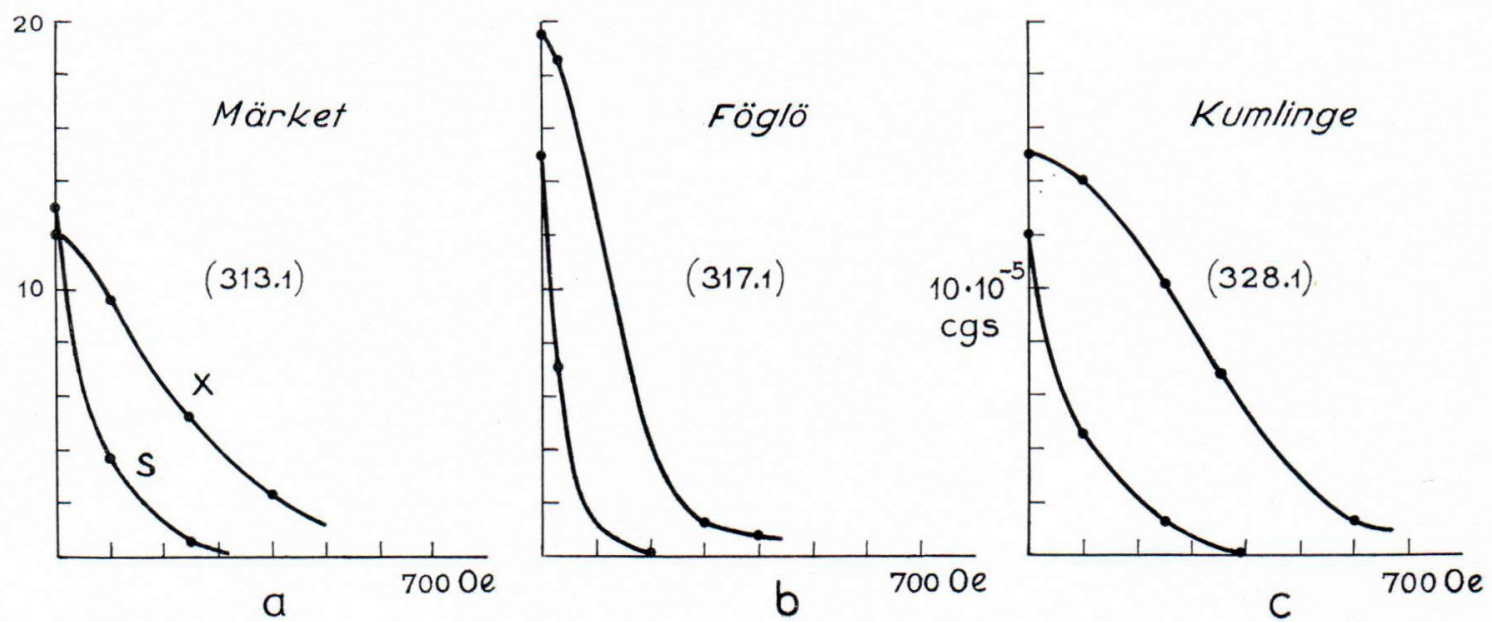

Fig. 2. Demagnetization curves of the pilot samples. $\mathrm{S}=$ weak unstable magnetization, $\mathrm{X}=$ stronger characteristic magnetization. Constructed according to Zijderveld (1967). 
TABLE 2

Remanent magnetization

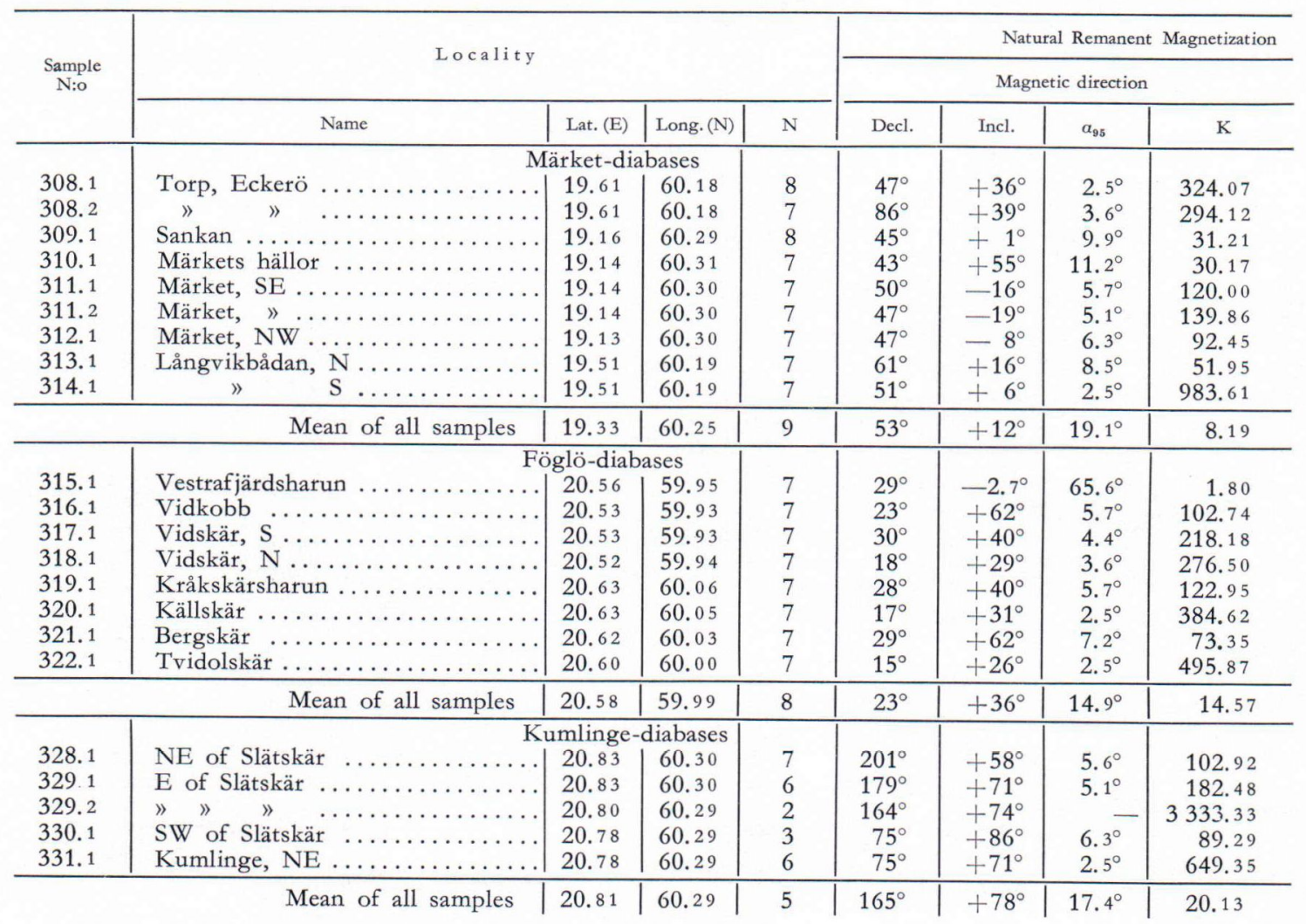

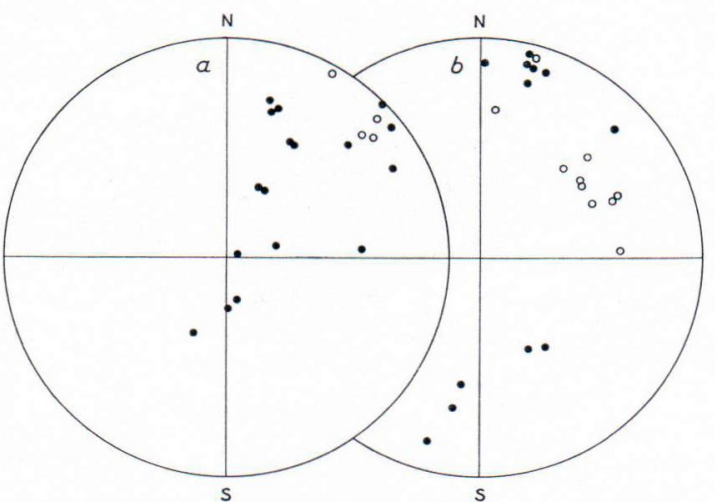

Fig. 3. Directions of remanent magnetization in equal area stereographic projection. a) before and b) after demagnetization. with a depth as described in connection with the Satakunta dolerites (Neuvonen, 1965). Pilot samples demagnetized in an increasing AC field showed the presence of a secondary remanent component (Fig. 2). The stable component, measured after demagnetization with a $350-400$ Oersteds peak field, is only a small fraction of the original NRM (Table 2). The depth effect disappears during the AC treatment giving reason to believe that the remaining stable magnetization could possibly be the original TRM.

After demagnetization, the samples were remeasured with a Förstermagnetometer (Oerstedmeter, Institute Dr. Förster, Reutlingen, Germany) using two pairs of differential sonds ('Type TGK-32-T9-4, spez). As seen in Fig. 3, 
of diabase dikes

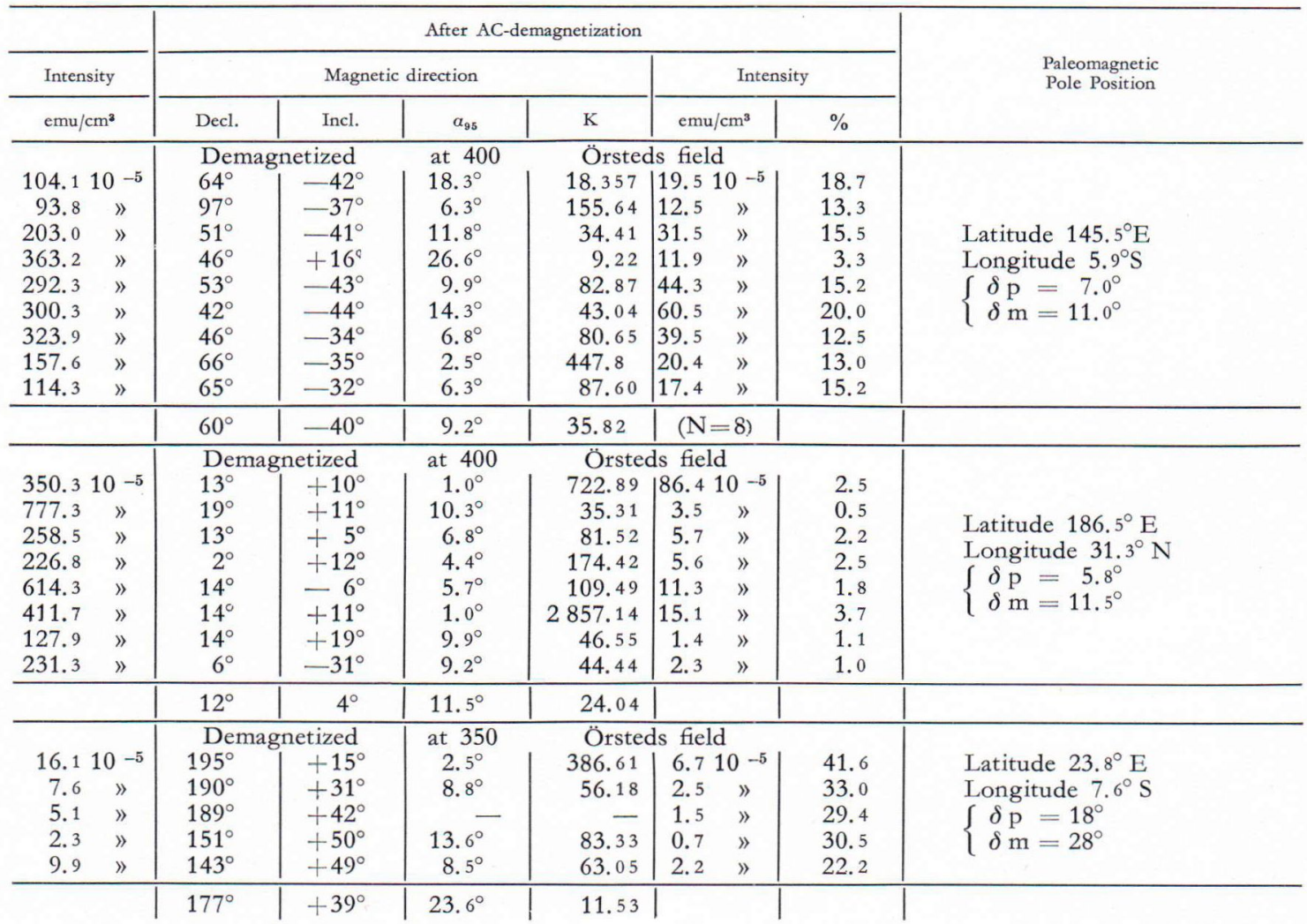

the directions of the remanent magnetization after demagnetization assemble in three different areas on the stereographic projection, each of which represents one of the types of dyke collected. The directions and the strength of the remanent magnetization after demagnetization are also listed in part two of Table 2. The paleomagnetic pole positions for each dike system are also given in Table 2 calculated according to the mean directions evaluated after Fisher (1953). The pole positions are shown in Fig. 4 and are compared with the positions obtained for the Satakunta and Vaasa dolerites. The circles of confidence( $\mathrm{p}=0.05)$ for the Aland poles are considerably larger than those of earlier measurements indicating wider spread in the directions.

\section{Discussion}

As pointed out e.g. by Storetvedt (1968), remagnetization is likely to have occurred in igneous rocks so that the measured directions of magnetization are not equivalent with the original TRM. Such a remagnetization due to slow cooling is also possible in broad dike rocks like those of the Märket and Föglö diabases. The bulk effect would not, however, be very large. On the other hand, deep burial in the earth's crust could easily remagnetize rocks of any kind since under such conditions the temperature might stay at considerably high values for long periods. The problem would, in principle, be the same as that pointed out by Neuvonen (1961) in 


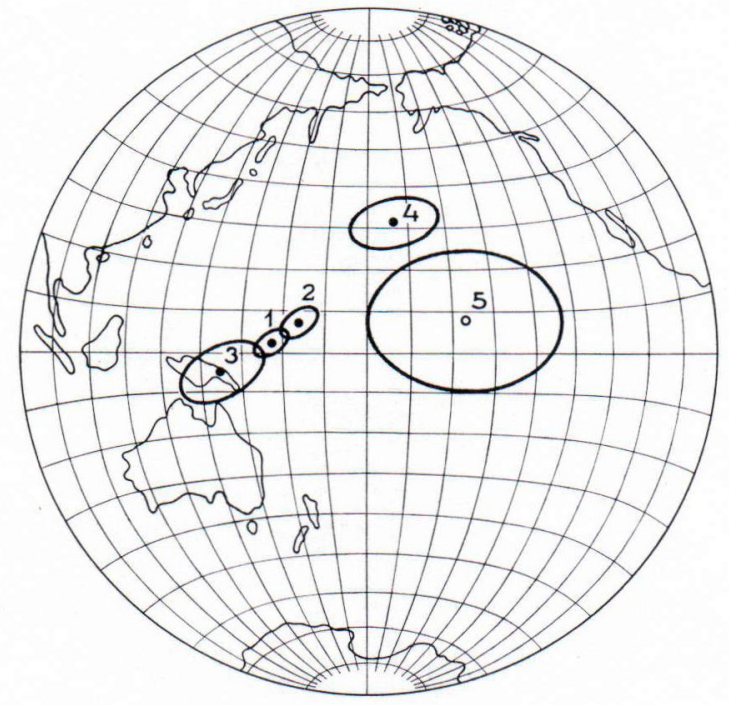

Fig. 4. Paleomagnetic pole positions. 1) Satakunta, 2) Vaasa, 3) Märket, 4) Föglö, and 5) Kumlinge diabase dikes (S-pole)

connection with the apparent age pattern of the crust. This type of burial reorientation is evidently very likely to have occurred in old rocks of Precambrian age. Consequently, in a territory of Precambrian rocks, one would expect regional magnetic reorientation in all kinds of rocks despite their age and origin. It is, therefore, surprising to observe three different directions of remanent magnetization in a relatively small area in the Aland archipelago. This indicates that the regional remagnetization due to deep burial has not occured in this area. In the Satakunta region the same fact is verified by the reorientation of the magnetic directions of the country rock only in the contact zone of the dolerite dikes parallel to that of the dolerite. Another explanation is that the different orientations observed are caused by large block movements. Such a mechanism could not, however, explain the presence of the reversed magnetization of the Kumlinge diabases.

The magnetic directions found after demagnetization can, therefore, be assumed, at least for the time being, to represent the original TRM of the different dike systems. Accordingly, the pole positions 4, 2, 1 and 3 in Fig. 4 could roughly indicate the wandering path of the paleomagnetic pole as indicated by the doleritic rocks of Föglö, Vaasa, Satakunta and Märket. All of these are younger than the rapakivi intrusion except the Föglö diabase (pole No 4 in Fig. 4) which might be a little older. Unfortunately, all attempts to determine the magnetic direction and corresponding pole position of the rapakivi granite and associated apophysic dikes have been unsuccesful so far. The pole position of the Kumlinge diabase dikes comes quite close to the path mentioned but is reversed. The divergence is not great and can well be caused by the nondipolar nature of the geomagnetic field. The age of the Kumlinge and Föglö dikes could, consequently, be much the same.

The radiometric ages of the different dike rocks measured are not yet known. As soon as they are available the interpretation of the magnetic directions will be simplified. It must be kept in mind that the directions now interpretated as representing the original TRM, could in fact be the sums of vectors of various ages and origins. The matter will be elucidated by the results obtained in the Ava region (Neuvonen, 1969) since they will present us with the first information concerning the magnetic direction of a rapakivi type intrusion in Finland.

Acknowledgements - Sincere thanks are due to all persons who assisted in collecting and preparing the samples, to The National Scientific Research Council for the grant which made this work possible and to Mrs. Lyyli Orasmaa for the drawings. 


\section{REFERENCES}

Frsher, R. A. (1953) Dispersion of a sphere. Royal Soc. London Proc., Ser. A, Vol. 217, pp. 295-305.

Frosterus, Benj. (1892) Om en diabas i Föglö i den åländska skärgården. Geol. Fören. Stockh. Förh. Bd. 15, pp. 275-290.

Hausen, Hans (1964) Geologisk beskrivning over Landskapet Åland. Skrifter utgivna av Ålands Kulturstiftelse IV.

Kaitaro, Simo (1953) Geologic structure of the late PreCambrian intrusives in the Åva area, Alands islands. Bull. Comm. géol. Finlande No 162.

Neuvonen, K. J. (1961) The apparent age pattern of the crust. Compt. Rend. Soc. géol. Finlande 33, pp. 445 -454 .

Neuvonen, K. J. (1969) Paleomagnetism of the dike systems in Finland. V. Remanent magnetization of the Âva intrusives. Bull. Geol. Soc. Finland, in press.

Sederholm, J. J. (1890) Från Ålands västra gräns. Geol. Fören. Stockh. Förh. Bd. 12, pp. 460-470.

Sederholm, J. J. (1934) Om migmatites and associated Pre-Cambrian rocks of southwestern Finland. Part III. The Åland Islands. Bull. Comm. géol. Finlande 107, pp. $1-68$.

Storetvedt, K. M. (1968) Om remagnetization problems in paleomagnetism. Earth and platetary Science letters 4, pp. 107-112.

Zijderveld, J. D. A. (1967) A. C. demagnetization of rocks: analysis of results. In D. W. Collison, K. M. Creer and S. K. Runcorn (editors) Methods in Paleomagnetism. Elsevier, Amsterdam, pp. 254-286.

Manuscript received, August 24, 1968. 